\title{
The Action of Phospholipase A and Lipid Solvents on Murray Valley Encephalitis Virus
}

\author{
By S. G. ANDERSON AND G. L. ADA \\ Walter and Eliza Hall Institute of Medical Research, Royal Melbourne Hospital \\ Post Office, Victoria, Australia, and the Department of Experimental Medicine, \\ University of Melbourne
}

(Received 25 January 1961)

\section{SUMMARY}

Phospholipase A (100 $\mu \mathrm{g} . / \mathrm{ml}$.) acting at $37^{\circ}$ for $30 \mathrm{~min}$. decreased the infective titre of crude or purified Murray Valley encephalitis (MVE) virus from 7 or 8 log to less than $1 \log$. This inactivated virus yielded 2 log of infective 'ribonucleic acid' ('RNA') when it was treated with phenol. Ether, chloroform or butanol acting at $0-4^{\circ}$ each decreased the infectivity of crude or purified MVE virus. Again the inactivated virus yielded 'RNA' with an infective titre higher than the titre of the inactivated virus. Infective 'RNA' prepared from crude MVE virus was not inactivated by ether, chloroform or butanol. High concentrations of phospholipase $\mathbf{A}$ preparations destroyed 'RNA', possibly due to traces of contaminating ribonuclease. The results suggest that intact viral phospholipid is necessary for infectivity of the virus particle.

\section{INTRODUCTION}

That arthropod-borne viruses contained lipid was first clearly shown by Taylor, Sharp, Beard \& Beard (1943) from a chemical analysis of eastern equine encephalomyelitis virus. Birch (1941) demonstrated the inactivation of an arthropod-borne virus (western equine encephalitis) by diethyl ether, and Hammon, Reeves \& Izumi (1942) described the inactivation of St Louis encephalitis virus by diethyl ether. Andrewes \& Horstmann (1949) introduced this reaction to assist in grouping viruses, and showed that ether decreased the titre of yellow fever virus by $3 \log$, and of louping ill by 2 log. Sunaga, Taylor \& Henderson (1960) found that ten arthropodborne viruses were decreased in titre by treatment with diethyl ether; for example a preparation of Japanese B encephalitis virus was decreased in titre from $3.5 \mathrm{log}$ to less than 1.0 log. The present paper examines the action of phospholipase $\mathbf{A}$, ether, chloroform and $n$-butanol on the infectivity of crude and purified preparations of the virus of Murray Valley encephalitis (MVE virus) and on the infective 'RNA' of this virus. Some of the present results with phospholipase A have already been published in brief (Anderson \& Ada, 1960). 


\section{METHODS}

Murray Valley encephalitis (MVE) virus. Crude virus was a $20 \%(\mathrm{w} / \mathrm{v})$ suspension of infected suckling mouse brain in phosphate buffered saline ( $\mathrm{pH} 7 \cdot 7)$. Purified virus was prepared by treatment with protamine, ultracentrifugation, adsorption to and elution from hydroxyl apatite and a second ultracentrifugation (Ada, Anderson \& Abbot, 1961). The purified virus (deposit from second centrifugation) was suspended in a solution containing $\mathrm{NaHCO}_{3}(0.025 \mathrm{M})$, cystine $(0.85 \mathrm{M}), \mathrm{NaCl}$ $(0 \cdot 15 \mathrm{M})$ and buffered with phosphate $(0 \cdot 25 \mathrm{M} ; \mathrm{pH} 7 \cdot 7)$.

'RNA' was prepared by phenol treatment of crude MVE virus (Anderson \& Ada, $1959 a$ ). This standard infective 'RNA' should be distinguished from the infective

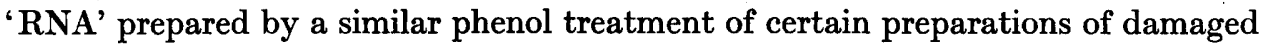
virus mentioned in the text.

Treatment of virus with deoxycholate. Sodium deoxycholate was added to virus suspensions to a final concentration of $1 \%(\mathrm{w} / \mathrm{v})$. The mixture was held at room temperature for ten minutes (Anderson \& Ada, $1959 b$ ).

Phospholipase A. This was isolated from the venom of the Black Snake (Pseudechis porphyriacus) according to Doery \& Pearson (1961). Before use the enzyme preparation was diluted in physiological saline ( $\mathrm{pH} 6 \cdot 0)$ to a concentration of $100 \mu \mathrm{g} . /$ $\mathrm{ml}$. and placed in a boiling water bath for $10 \mathrm{~min}$.

Ribonuclease (Worthington or Delta) was diluted in physiological saline before use.

Lysolecithins. These were prepared by the action of phospholipase $\mathbf{A}$ on egg lecithin and L-a-(dimyristoyl) lecithin (Doery \& North, 1960) and supplied to us by Miss $\mathbf{H}$. Doery.

n-Butanol. Laboratory grade reagent was redistilled and a fraction with a boiling point range $116^{\circ}-118^{\circ}$ was used.

Chloroform. Anaesthetic grade was used.

Ether. Diethyl ether was prepared for use as described previously (Anderson \& Ada, 1959a).

Phosphate buffered $(P B)$ saline. An aqueous solution containing $\mathrm{NaH}_{2} \mathrm{PO}_{4}$ $(0.05 \mathrm{M}), \mathrm{NaOH}(0.044 \mathrm{M})$ and $\mathrm{NaCl}(0 \cdot 13 \mathrm{M}),(\mathrm{pH} 7 \cdot 7)$ was used.

Normal baby mouse brain extract (BMBE). This was a $20 \%(\mathrm{w} / \mathrm{v})$ emulsion in PB saline of brains of mice 8-10 days old. The product was centrifuged $(2000 \mathrm{~g}$, 5 min., $0-4^{\circ}$ ) and used fresh.

Normal rabbit serum. Rabbits were bled from the ear vein and the serum separated at $37^{\circ}$. Pooled serum was filtered through a Seitz filter pad and stored at $-20^{\circ}$. As diluent for virus it was used as a $10 \%$ dilution in physiological saline.

Treatment of virus or ' $R N A$ ' with lipid solvent. Two volumes of solvent were added to one volume of virus or 'RNA' contained in a glass-stoppered bottle big enough for the bottle to be less than half full. The mixture was shaken (100 strokes/min.; amplitude $5 \mathrm{~cm}$.) at $0^{\circ}$ for the appropriate time.

Titrations of infectivity for virus and ' $R N A$ '. Titration in 12-day chick embryos was done on the chorioallantoic membrane, the membranes being 'dropped' with the inoculum of $0.05 \mathrm{ml}$. The infectivity was determined as the $50 \%$ lethal endpoint at 3 days. 


\section{RESULTS}

\section{Action of phospholipase $A$ on $M V E$ virus}

Crude MVE virus was mixed with phospholipase $\mathbf{A}$ to a final concentration of $100 \mu \mathrm{g}$. enzyme $/ \mathrm{ml}$., and the mixture held at $37^{\circ}$ for $30 \mathrm{~min}$. The infective titre decreased from $7 \cdot 0$ to $0.4 \mathrm{log}$, while virus in a control preparation did not decrease in titre. Both the control and the enzyme-treated virus were then treated with phenol by the standard method for preparation of infective 'RNA'. Control virus yielded $4.5 \log$ of infective 'RNA', enzyme-treated virus yielded 2.5 log of 'RNA'. Purified MVE virus gave essentially similar results (Table 1).

Table 1. Action of phospholipase $A$ (100 $\mu \mathrm{g} . / \mathrm{ml}$.$) on M V E$ virus $\left(37^{\circ}, 30 \mathrm{~min}.\right)$

\begin{tabular}{|c|c|c|}
\hline & $\begin{array}{l}\text { Control } \\
\text { virus* }\end{array}$ & $\begin{array}{l}\text { Virus treated } \\
\text { with phospho- } \\
\text { lipase A }\end{array}$ \\
\hline \multicolumn{3}{|l|}{ Crude virus } \\
\hline Titre of virus & $7 \cdot 0 \dagger$ & $0 \cdot 4$ \\
\hline Titre of 'RNA' & 4.5 & $2 \cdot 5$ \\
\hline \multicolumn{3}{|l|}{ Purified virus } \\
\hline Titre of virus & 8.0 & $0 \cdot 6$ \\
\hline Titre of 'RNA' & $5 \cdot 0$ & $1 \cdot 6$ \\
\hline
\end{tabular}

* Control virus held at $37^{\circ}$ for 30 min. in absence of phospholipase A.

$\dagger \log _{10}$ infectivity titre.

$\ddagger$ 'RNA' was prepared by the action of phenol on virus which had been held at $37^{\circ}$ for $30 \mathrm{~min}$., either with or without phospholipase $A$.

The activity of phospholipase $\mathbf{A}$ against virus was titrated in the above system. Serial 10-fold dilutions of enzyme were mixed with equal volumes of virus and incubated at $37^{\circ}$ for 30 min.; control virus was incubated without enzyme. The endpoint was taken as the concentration of enzyme which destroyed $2 \mathrm{log}$ of infectivity. The titre against either undiluted crude virus or crude virus diluted $1 / 10^{4}$ in baby mouse brain extract (BMBE) was $0.05 \mu \mathrm{g} . / \mathrm{ml}$. in each of three determinations. The titre was much lower $(10 \mu \mathrm{g} . / \mathrm{ml}$.) in the presence of normal rabbit serum (Table 2).

Table 2. Titre* of phospholipase $A$ against $M V E$ virus

$\begin{array}{lcc}\text { Medium and dilution } & \begin{array}{c}\text { Crude virus } \\ (\mu \mathrm{g} . / \mathrm{ml} .)\end{array} & \begin{array}{c}\text { Purified virus } \\ (\mu \mathrm{g} . / \mathrm{ml} .)\end{array} \\ \text { Undiluted } & \mathbf{0 . 0 5} & \mathbf{0 . 1 - 2 . 0} \\ \text { Undiluted + BMBE } \dagger & 0.05 & \mathbf{0 . 6} \\ \text { Undiluted + NRS } \ddagger & - & \mathbf{6 . 0} \\ \text { Diluted } 10^{-4} \text { in BMBE } & 0.05 & 0.05 \\ \text { Diluted } 10^{-4} \text { in NRS } & 10.0 & >\mathbf{3 0 . 0}\end{array}$

* Concentration of phospholipase which destroyed 2 logs of infectivity in $30 \mathrm{~min}$. at $37^{\circ}$.

$\uparrow$ BMBE, an emulsion of normal baby mouse brain.

$\ddagger$ NRS, normal rabbit serum.

The titre against undiluted purified virus varied between $2 \cdot 0$ and $0 \cdot 1 \mu \mathrm{g} . / \mathrm{ml}$. (mean $0.9 \pm 0.78$ s.D.) over a series of 10 experiments. Purified virus is known to be relatively unstable in the absence of either serum or normal brain extract, and 
although the controls in these ten experiments were satisfactory, the extremely wide variation in endpoints was ascribed to the instability of purified virus. As with crude virus, so here the enzymic action was inhibited by normal rabbit serum. The above results were obtained with boiled preparations of the enzyme. If instead of being boiled the purified phospholipase was used unheated, the titres against pure and crude virus were about tenfold higher.

A mixture of phospholipase $(10 \mu \mathrm{g} . / \mathrm{ml}$.) and pancreatic ribonuclease $(0 \cdot 1 \mu \mathrm{g} . / \mathrm{ml}$.) was used to inactivate crude virus. The inactivation was slightly greater than with phospholipase alone (Table 3), but the product still yielded 'RNA' with a titre higher than the titre of treated virus from which it was derived. An incidental finding was that phospholipase $\mathbf{A}$ even in concentrations of $1 \mathrm{mg} . / \mathrm{ml}$. was harmless to the chick embryo when inoculated on to the chorioallantoic membrane. This enzyme is the active agent in certain snake venoms, and relatively small amounts were lethal when injected into chick embryo itself.

\section{Action of phospholipase $A$ on ' $R N A$ '}

Standard infective 'RNA' was treated with phospholipase A as described for virus. One batch of enzyme gave an end-point (destruction of $2 \mathrm{log}$ of infectivity) of 'RNA' at $100 \mu \mathrm{g} . / \mathrm{ml}$. and a second batch at $1 \mathrm{mg} . / \mathrm{ml}$. Each titration had a characteristically flat end-point, an indication that the destruction of ' $R N A$ ' may have continued after dilution of inoculum and after inoculation into eggs. Baby mouse brain extract (BMBE) had previously been found to be a diluent in which 'RNA' was relatively stable. However, in the presence of BMBE, 'RNA' was readily inactivated by phospholipase $A$, and the enzyme had an end-point at $0.05 \mu \mathrm{g} . / \mathrm{ml}$.

Table 3. Infectivity remaining after treatment of crude $M V E$ virus with enzymes

Mixture incubated $37^{\circ}, 30 \mathrm{~min}$.

Virus alone

Virus + phospholipase A (10 $\mu \mathrm{g} . / \mathrm{ml}$.)

Virus + RNAse $(0 \cdot 1 \mu \mathrm{g} . / \mathrm{ml}$.)

Vitus + phospholipase $(10 \mu \mathrm{g} . / \mathrm{ml}$.) + RNAse (0.1 $\mu \mathrm{g} \cdot / \mathrm{ml}$.)

$\begin{array}{cc}\begin{array}{c}\text { Titre of } \\ \text { virus }\end{array} & \begin{array}{c}\text { Titre of } \\ \text { 'RNA'* }\end{array} \\ 7 \cdot 0 & 4 \cdot 6 \\ \mathbf{2 \cdot 3} & 4 \cdot 2 \\ \mathbf{7 \cdot 2} & \mathbf{5 \cdot 0} \\ \mathbf{1 \cdot 2} & \mathbf{2 \cdot 7}\end{array}$

* 'RNA' made by the action of phenol on the corresponding mixture which had been incubated at $37^{\circ}$ for $30 \mathrm{~min}$.

\section{Action of ether on virus and ' $R N A$ '}

At $4^{\circ}$ ether decreased the infectivity of crude MVE virus by about $3 \log$ in $5 \mathrm{~min}$. (Table 4). No further infectivity was lost between $60 \mathrm{~min}$. and $18 \mathrm{hr}$. Thus $0 \cdot 1 \%$ of the original crude virus was resistant to treatment for $18 \mathrm{hr}$. with ether at $4^{\circ}$. This resistant virus was studied. Ether resistance was phenotypic and not genotypic; this was shown by an experiment in which two serial limit-dilution passages of the treated virus were made in eggs and the resultant virus used to infect suckling mice. The progeny was as susceptible to ether as was the original stock virus.

Ether-resistant virus was not inactivated by ribonuclease, but some preparations were rather unstable at $37^{\circ}$. It was not clear whether this was intrinsic instability of ether-resistant virus, or due to the continued action of ether at $37^{\circ}$. Virus partly inactivated by ether was treated with phenol or deoxycholate to yield 'RNA'. The 
titre of the yield was similar to that from the original stock virus (Table 4). Etherresistant virus was completely inactivated by phospholipase $\mathbf{A}$ but the enzyme did not decrease the titre of potential infective ' $R N A$ ' $(2 \cdot 2$ log compared to the control figure $2.5 \mathrm{log}$ ). Purified MVE virus was more completely inactivated by ether than was the crude virus, but again the reaction did not decrease the potential yield of 'RNA' (Table 4). Standard infective 'RNA' was normally freed from phenol by washing with ether. A sample of infective 'RNA' before and after such washing had titres $5 \cdot 0$ and $5 \cdot 2 \mathrm{log}$, respectively, which showed that ether had not decreased the infectivity of 'RNA'.

Table 4. Action of diethyl ether on $M V E$ virus at $4^{\circ}$

\begin{tabular}{|c|c|c|c|}
\hline & Duration of treatment & $\begin{array}{c}\text { Titre of } \\
\text { virus }\end{array}$ & $\begin{array}{l}\text { Titre of } \\
\text { 'RNA'* }\end{array}$ \\
\hline Crude virus & $\begin{array}{l}0 \mathrm{~min} \\
5 \mathrm{~min} . \\
60 \mathrm{~min} . \\
18 \mathrm{hr} .\end{array}$ & $\begin{array}{l}7 \cdot 0 \\
4 \cdot 2 \\
3 \cdot 5 \dagger \\
3 \cdot 6\end{array}$ & $\begin{array}{l}4.5 \\
4 \cdot 3 \ddagger \\
4 \cdot 4\end{array}$ \\
\hline Purified virus & $\begin{array}{l}0 \mathrm{~min} . \\
18 \mathrm{hr} . \text { alone (control) } \\
18 \mathrm{hr} \text {. with ether }\end{array}$ & $\begin{array}{r}10 \cdot 4 \\
8 \cdot 3 \\
1 \cdot 2\end{array}$ & $\begin{array}{l}-\overline{4 \cdot 0} \\
3 \cdot 9\end{array}$ \\
\hline
\end{tabular}

* 'RNA' made by the action of phenol on the ether treated virus.

$\dagger$ Not destroyed by RNAse $\left(0 \cdot 1 \mu \mathrm{g} . / \mathrm{ml} .37^{\circ} ; 30 \mathrm{~min}.\right)$.

$\ddagger$ Destroyed by RNAse (0.01 $\mu \mathrm{g} . / \mathrm{ml} .37^{\circ} ; 30 \mathrm{~min}$.).

Action of butanol, chloroform and lysolecithin on virus and ' $R N A$ '

$B$ utanol decreased the titre of crude virus from $7 \cdot 6 \log$ to zero in $15 \mathrm{~min}$. at $4^{\circ}$. Some infective 'RNA' could still be recovered even after prolonged treatment of virus (Table 5). Butanol alone (60 min.) was without effect on the infectivity of undiluted 'RNA'; but a mixture of butanol and baby mouse brain extract destroyed 'RNA', decreasing the titre from 5.2 to $1.5 \log$ in 60 min. at $4^{\circ}$, or from $5.2 \log$ to zero in $30 \mathrm{~min}$. at $20^{\circ}$. This finding suggested one possible explanation of the low yield of 'RNA' from butanol treated crude virus (Table 5).

Chloroform. When exposed to chloroform the titre of crude virus fell from $7 \cdot 0$ to $1 \cdot 8 \log$ after $2 \frac{1}{2} \mathrm{hr}$. ' $R N A$ ' was recovered from the inactivated virus, and had a titre of $4 \cdot 4 \log$.

Table 5. Action of butanol on MVE virus (60 min., $4^{\circ}$ )

$\begin{array}{lcc}\text { Reaction mixture } & \begin{array}{c}\text { Infective } \\ \text { titre of } \\ \text { reaction } \\ \text { mixture }\end{array} & \begin{array}{c}\text { Titre of } \\ \text { 'RNA'* }\end{array} \\ \text { Crude virus alone } & \mathbf{7 \cdot 6} & \mathbf{5 \cdot 0} \\ \text { Crude virus }+n \text {-butanol } & \mathbf{0 \cdot 0} & \mathbf{0 \cdot 8} \\ \text { Pure virus alone } & \mathbf{8 \cdot 4} & \mathbf{4 \cdot 2} \\ \text { Pure virus }+n \text {-butanol } & \mathbf{1 \cdot 3} & \mathbf{3 \cdot 0}\end{array}$

* 'RNA' made by the action of phenol on the final reaction mixture.

Lysolecithin. This agent was allowed to act at $37^{\circ}$ for $30 \mathrm{~min}$. The $2 \log$ destruction end-point against MVE virus was at $500 \mu \mathrm{g}$. lysolecithin $/ \mathrm{ml}$. It was not clear, however, whether the lysolecithin itself was acting, or whether the activity was due 
to contaminating phospholipase remaining from the process of manufacture of lysolecithin. Approximately 100 parts phospholipase/million could have produced this result.

\section{DISCUSSION}

The infectivity of both crude and purified MVE virus was decreased by purified phospholipase $\mathbf{A}$ and by diethyl ether, chloroform and $n$-butanol. The effective action was clearly on the virus preparation and not on the host chorioallantoic membrane, because dilution of treated virus did not restore infectivity. The interpretation of the destruction of virus by the phospholipase $\mathbf{A}$ preparation depends on an assessment of the purity of both the enzyme and the virus. Any contaminating enzyme in the phospholipase $\mathbf{A}$ must have survived boiling and few known enzymes are so heat stable. The most likely one would be an alkaline ribonuclease. As the virus particle is known to be stable to pancreatic alkaline ribonuclease, the virus inactivating principle in the preparation was most probably phospholipase A. The purity of the virus could not be estimated accurately, but the purified product seemed to be largely viral substance (Ada et al. 1961). Although crude MVE virus was grossly impure from a chemical point of view, the pattern of destruction of crude virus by phospholipase A was not obviously different from that of purified virus. These considerations suggested that the enzymic inactivation of virus was due to the cleavage by phospholipase A of fatty acid(s) from viral phospholipid(s). Lack of sufficient purified MVE virus has so far prevented search for split products.

The three solvents may have acted on the virus by attacking lipid components but there is as yet no direct evidence for this view. The rapid and complete inactivation of virus by $n$-butanol may be related to its reported efficiency in extracting phospholipids (Morton, 1950). The actions of diethyl ether and deoxycholate were studied separately by Andrewes \& Horstmann (1949) and Burnet \& Lush (1940), and the results were compared by Sunaga et al. (1960), who added several findings and concluded that the two agents were strikingly similar in their actions on viruses. Our work did, however, show one difference: while higher concentrations of deoxycholate liberated infective 'RNA' from virus (Anderson \& Ada, 1959b), an aqueous solution of ether did not do so.

When we considered the significance of our results, the possibility that enzyme or solvent opened the virus particle and exposed the generic RNA to ambient ribonuclease was discarded, because higher titre ' $R N A$ ' could be recovered from the treated virus. The simplest interpretation and one most in line with current ideas, is that an intact phospholipid component on the virus particle is necessary during infection of the chorioallantoic membrane. An intact lipid envelope might enable the virus to penetrate the lipid layer of the surface of the host cell; or lipid components might be necessary for the integrity of specific receptor sites on the virus, which might function during entry into the host cell or during the early intracellular reactions of the virus. Another possibility cannot yet be eliminated. It is that lipid forms part of the mechanical structure of the virus particle although it does nothing specific in the process of infection of the host cell by virus. On this view enzymic or solvent alteration of viral lipid would distort viral architecture in such a way as to render the virus non-infective. 
The small proportion of virus particles which resisted the action of ether at $4^{\circ}$ was phenotypically but not genotypically distinct from the majority. This might suggest that the viral component attacked by ether was not directly genotypically determined, that it was not synthesized or incorporated under the immediate direction of the viral genome. It is tempting to believe that this ether-sensitive component is lipid, and indeed host lipid, and that it becomes wrapped around the virus particles just as the latter leave the host cell.

Because of the high concentration of phospholipase required to attack ' $R N A$ ', and also because of the differences of the titre between batches of phospholipase, it seemed possible that the action on 'RNA' was mediated not by the enzyme phospholipase A but by a contaminating heat stable ribonuclease. Previous titrations of pancreatic ribonuclease had shown a 2 log destructive end-point at 0.0007 $\mu \mathrm{g}$. ribonuclease/ml. (Anderson \& Ada, 1959a). Thus 7 parts of such ribonuclease/ million in the first batch of phospholipase, or 0.7 parts/million in the second batch, would have been sufficient to account for this destruction of 'RNA' by the preparation of phospholipase A used. It is not suggested that the active agent in the preparation of phospholipase was precisely similar to pancreatic ribonuclease, but only that it was able to attack 'RNA' sufficiently to destroy infectivity. If this be accepted, it follows that the ' $\mathbf{R N A}$ ' is insusceptible to phospholipase $\mathbf{A}$, and presumably lacks those phospholipid components which have been postulated as necessary for infectivity of the intact virus. The resistance of ' $R N A$ ' to the three solvents also supports this conclusion. The destruction of 'RNA' by mixtures of normal baby mouse brain emulsion with either butanol or phospholipase suggests that the latter two reagents liberated, from BMBE, factors destructive for ' $R N A$ '. It is pertinent to inquire whether these two factors may be identical, and whether they are ribonucleases.

In conclusion, we are inclined to adopt the second of the three alternatives discussed above, and to believe that MVE virus has one or more specific surface groups containing phospholipid, and that these play a vital role during infection of the host cell. Since 'RNA' is much less susceptible to phospholipase $\mathbf{A}$ and solvents than is intact virus, we must assume that ' $R N A$ ' neither possesses such groups nor needs them to effect entry into the susceptible cells of the chick embryo.

This work was assisted by a grant from the National Health and Medical Research Council, Australia. We are grateful to Miss H. M. Doery for samples of phospholipase A and lysolecithin. During this work we had helpful discussions with Drs A. W. Turner, A. W. Rodwell and P. Plackett (of C.S.I.R.O., Melbourne) and with Dr E. A. North and Miss H. M. Doery of the Commonwealth Serum Laboratories, Melbourne. The authors are also indebted to Margaret McElroy for excellent technical assistance.

\section{REFERENCES}

Ada, G. L., Anderson, S. G. \& Aвbot, A. (1961). Purification of Murray Valley encephalitis virus. J. gen. Microbiol. 24, 177.

Anderson, S. G. \& ADA, G. L. (1959a). Murray Valley encephalitis virus: preparation of an infective 'ribonucleic acid' fraction. Aust. J. exp. Biol. med. Sci. 37, 353.

Anderson, S. G. \& AdA, G. L. (1959b). Some aspects of the reaction between crude Murray Valley encephalitis (MVE) virus and deoxycholate. Virology, 8, 270. 
Anderson, S. G. \& ADA, G. L. (1960). A lipid component of Murray Valley encephalitis virus. Nature, Lond. 188, 876.

Andrewes, C. H. \& Horstmann, D. (1949). The susceptibility of viruses to ethyl ether. J. gen. Microbiol. 3, 290.

Birch, F. M. (1941). 'Studies on equine encephalomyelitis'. Amer. J. vet. Res. 2, 221.

Burnet, F. M. \& Lush, D. (1940). The action of certain surface active agents on viruses. Aust. J. exp. Biol. med. Sci. 18, 141.

Doery, H. M. \& North, E. A. (1960). Factors involved in the action of venoms against bacterial toxins in experimental animals. Brit. J. exp. Path. 41, 243.

Doery, H. M. \& Pearson, J. E. (1961). Haemolysins in venoms of Australian snakes. Observations on the haemolysins of the venoms of some Australian snakes and the separation of phospholipase A from the venom of Pseudechis porphyriacus. Biochem. $J$. 78, 820.

Hammon, W. McD., Reeves, W. C. \& Izumi, E. M. (1942). Mosquitoes and encephalitis in the Yakima Valley Washington. II. Methods for collecting arthropods and for isolating western equine and St Louis viruses. J. infect. Dis. 70, 267.

Morton, R. K. (1950). Separation and purification of enzymes associated with insoluble particles. Nature, Lond. 166, 1092.

Sunaga, H., TAYlor, R. M. \& Henderson, J.R. (1960). Comparative sensitivity of viruses to treatment with diethyl ether and sodium deoxycholate. Amer. J. trop. Med. Hyg. 9, 419.

TaYlor, A. R., Sharp, D. G., Beard, D. \& Beard, J. W. (1943). Isolation and properties of the equine encephalomyelitis virus (eastern strain). J. infect. Dis. 72, 31. 